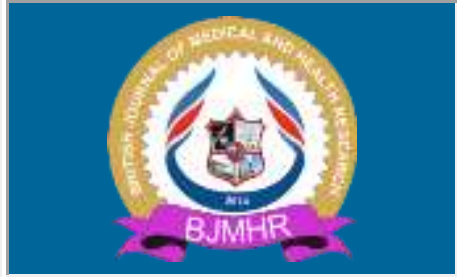

\title{
BJMHR
}

British Journal of Medical and Health Research Journal home page: www.bjmhr.com

\section{Possible Ameliorative Effects of Moringa Olifera in Inhibiting Toxicity of Adriamycin In Male Rats}

\author{
Abdel Karim M. Abdel Latif, Ahmed Ali Khandel, Basma A. Kelani and Khalid H. \\ Zaghloul \\ Zoology Department, Faculty of Science, Fayoum University, Egypt.
}

\section{ABSTRACT}

The present investigation aimed to study the protective effects of aqueous extract of Moringa olifera (MOR) leaf powder against the side effects of Adriamycin ADR (an anthracycline antibiotic, used in tumor therapy) on the hematological and biochemical functions of male albino rats. Animal's studies and drug treatment: 48 male albino rats weighing $180 \pm 10.0$ gm were taken and divided into six groups each one consists of 8 male rats. The $1^{\text {st }}$ group was fed ad-libitum with saline without any treatment so called control. The $2^{\text {nd }}$ group received MOR leaf powder aqueous extract orally with a daily dose $144 \mathrm{mg} / \mathrm{Kg}$ body weight for 30 days. The $3^{\text {rd }}$ one is ADR group where the animals were injected intraperitoneal (IP) from the first day in six equal injections of ADR (each containing $3 \mathrm{mg} / \mathrm{kg}$ b.wt.) over a period of two weeks (total cumulative dosage of $18 \mathrm{mg} / \mathrm{kg}$ body weight). The $4^{\text {th }}$ is ADR then MOR post-treated group where animals administered the same six injections of ADR dose of thereafter they were given the aqueous MOR leaf powder extract orally from day 20 . The $5^{\text {th }}$ is ADR/MOR treated group where animals received six equal injections of ADR over a period of 19 days and given concomitant orally a daily dose of MOR leaf powder aqueous extract of $144 \mathrm{mg} / \mathrm{kg}$ of body weight for 30 days. The $6^{\text {th }}$ group was (MOR pretreated then ADR group) where animals given orally once daily dose of MOR aqueous extract of $144 \mathrm{mg} / \mathrm{Kg}$ b. wt for 30 days and at the $11^{\text {th }}$ day received the six equal injections of ADR over a period of 19 days. The results revealed loss in body weight, an increase in mortality rate, disturbances in hematological parameters, liver and kidney functions of rats treated with adriamycin. In contrast, the Moringa improves the studied parameters to levels more or less similar to that of control group. This study revealed that Moringa may ameliorate the effect of ADR especially in the group that pretreated with Moringa before Adriamycin treatment.

Keywords: Adriamycin, Moringa, Blood parameters, liver and kidney functions, histopathology, rats.

*Corresponding Author Email: ama20@ fayoum.edu.eg

Received 20 September 2019, Accepted 01 October 2019

Please cite this article as: Latif A et al., Possible Ameliorative Effects of Moringa Olifera in Inhibiting

Toxicity of Adriamycin In Male Rats. British Journal of Medical and Health Research 2019. 


\section{INTRODUCTION}

Chemotherapy has been known to be the best effective therapy (1). However, all the used drugs for cancer therapy are not specific on cancer cells, in that they do not only affect the proliferated cells, but also the normal cells. Adriamycin (ADR) (also named doxorubicin) is an anthracycline antibiotic that has been used for more than 30 years for the treatment of a wide variety of cancers. It is obtained from Streptomyces peucetius, although a total chemical synthesis is now possible $\left(^{2-4}\right)$. In addition, the acute side effects, which may develop within minutes after intravenous administration of the drug, are nausea, vomiting, myelo-suppression and arrhythmias and the chronic side effects, that may develop several weeks or months after repetitive doxorubicin administration. These effects are irreversible and have a grave prognosis $\left(\mathbf{(}^{\mathbf{2}}, \mathbf{)}\right)$. ADR-induced nephropathy has been well characterized in rodents and demonstrated to include albuminuria, impaired glomerular function, glomerulosclerosis, morphological changes and other features $\left({ }^{\mathbf{6}, 7}\right)$.

The need for antioxidants becomes even more critical with increased exposure to free radicals because they are our first line of defense against free radical damage ${ }^{8}$ ). Moringa oleifera Lam. (Moringaceae) is best known as excellent source of nutrition and a natural energy booster. Various parts of this plant such as the leaves, roots, seed, bark, fruit, flowers and immature pods act as antioxidant, antibacterial, hepatoprotective and antifungal activities, and are being employed for the treatment of different ailments in the indigenous system of medicine ${ }^{(9)}$ ). It is a small or medium sized tree up to $10 \mathrm{~m}$ tall, with thick, soft, corky, deeply fissured bark, growing mainly in semiarid, tropical and subtropical areas $\mathbf{( 1 0}^{\mathbf{1 0}}$. The antioxidant activity of $M$. oleifera leaves might be attributed to the presence of high amount of flavonoids, polyphenolics and tocopherol contents $\left({ }^{11}\right)$. So that the studies indicated the medicinal value of $M$. oleifera in terms of cancer chemotherapy and chemoprevention $\mathbf{( 1 2}^{\mathbf{1 2}}$. So the aim of the present investigation is to elucidate whether the aqueous extract of Moringa leaf powder may elicit an antagonistic effect against hepatotoxicity and nephrotoxicity of Adriamycin on male albino rats. 


\section{MATERIALS AND METHOD}

Forty-eight healthy adult male Swiss Albino rats, weighing $180 \pm 10 \mathrm{gm}$, were obtained from the experimental animal house of the National cancer institute (NCI), Cairo University, Egypt. The animals were kept under standard environmental conditions on 12 hours light/dark cycle under a constant temperature of $(25 \pm 1){ }^{\circ} \mathrm{C}$ and free access to food and water was allowed all the time. Rats were acclimated to laboratory conditions for 30 days prior to experiments. Rats were housed eight per cage in the sterilized plastic cages with wood shaving bedding.

\section{The natural product used:}

Commercial name: Moringa. Scientific name: Moringa oleifera Lam. (M. oleifera): Moringa used as capsules powder that can be taken orally in aqueous solution to rats as we did in the experiment.

\section{Moringa preparation:}

Moringa used as capsules that had been taken orally to rats as we did, each capsule weigh 400 mg.

\section{Moringa (800mg) Description from Genesis Today}

Discover one of Africa's best kept secrets for weight management and healthy nutrition. Fondly called "The Miracle Tree," the magnificent Moringa boasts incredible amounts of key nutrients, including vitamins, minerals, amino acids and antioxidants that satisfy the body's hunger for healthy nutrition, supporting balanced blood sugar, healthy energy and powerful weight control. Our $100 \%$ pure Moringa product contains only wild-harvested Moringa leaves in a vegetarian capsule with absolutely no binders, no fillers and no excipients!

\begin{tabular}{|c|c|c|c|}
\hline Supplement Facts & oc Per Con & r. 30 & 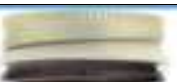 \\
\hline Ingredient & Amount & \% Daily Value** & \\
\hline $\begin{array}{lll}\text { Moringa } & \text { Oleifera } & \text { (leaf) } \\
\text { Powder } & & \end{array}$ & $800 \mathrm{mg}$ & & \\
\hline $\begin{array}{l}* * \text { Percent Daily Value is base } \\
\text { values may be higher or lower } \\
\dagger \text { Daily Value not established }\end{array}$ & $\begin{array}{l}\text { on a } 2000 \\
\text { epending }\end{array}$ & $\begin{array}{l}\text { rie diet. Your daily } \\
\text { ur calorie needs }\end{array}$ & \\
\hline
\end{tabular}

Ingredients: Other Ingredients: Vegetable capsule

\section{Manufacturer's Directions}

As a dietary supplement, take two (2) capsules one or more times per day 30 minutes before meals with a full glass of water or as recommended by your healthcare provider. Enjoy \& live long! Do not use if seal around cap is broken. Keep out of reach of children.

https://www.allstarhealth.com/f/genesis_today-moringa_(800mg).htm 


\section{ADRIAMYCIN}

Adriamycin was purchased as DOX hydrochloride (vial of $25 \mathrm{ml}$ contains: $50 \mathrm{mg}$ Doxorubicin $\mathrm{HCl}$ ) from Pfizer Pharma, Egypt) and all other reagents were of analytical grade and were purchased from commercial suppliers. Adriamycin was administrated (intraperitoneal) in six equal injections (each containing $3 \mathrm{mg} / \mathrm{kg}$ b.wt.) over a period of 18 days, with a total cumulative dosage of $18 \mathrm{mg} / \mathrm{kg}$ body weight $\left({ }^{13,14}\right)$. The chemical name of doxorubicin $\mathrm{HCl}$ is $(8 \mathrm{~S}, 10 \mathrm{~S})$ - 10- [(3-amino-2,3,6-trideoxy- $\alpha$-Llyxohexopyranosyl)oxy] - 8-glycolyl 7, 8, 9, 10 - tetrahydro - 6, 8, 11 trihydroy - 1- methoxy - 5, 12 naphthacenedione hydrochloride. The molecular formula is $\mathrm{C} 27-\mathrm{H} 29-\mathrm{NO} 11 \cdot \mathrm{HCl}$; its molecular weight is $579.99\left({ }^{15}\right)$.

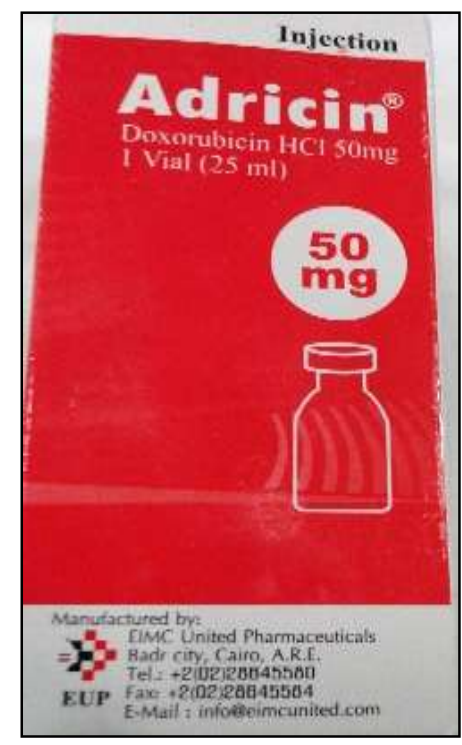

ALT, AST, Creatinine and Urea assay kits: were obtained from Randox, Egypt.

\section{Experimental design:}

$1^{\text {st }}$ Group: Control group: Animals were injected once normal saline $0.9 \% \mathrm{Na} \mathrm{Cl}$ (0.2 $\mathrm{ml}$, intraperitoneal) daily injected with saline from day 1 to the end of experiment (till 30 days). $2^{\text {nd }}$ Group: Moringa group: The animals were administrated orally and daily with aqueous solution containing $144 \mathrm{mg} / \mathrm{kg}$ body weight of $M$. oleifera till 30 days. $3^{\text {rd }}$ Group: Adriamycin group: The animals were injected intraperitoneal (IP) from the first day in six equal injections of ADR (each containing $3 \mathrm{mg} / \mathrm{kg}$ b.wt.) over a period of 19 days, with a total cumulative dosage of $18 \mathrm{mg} / \mathrm{kg}$ body weight. $4^{\text {th }}$ Group: ADR then MOR group: Animals were injected intraperitoneal (IP) from the first day in six equal injections of ADR (each containing $3 \mathrm{mg} / \mathrm{kg}$ b.wt.) over a period of 19 days (cumulative dosage of 18 $\mathrm{mg} / \mathrm{kg}$ body weight) then from day 20 to day 30 they were given orally once daily aqueous solution containing $144 \mathrm{mg} / \mathrm{kg}$ body weight of $M$. oleifera. $5^{\text {th }}$ Group: MOR = ADR group: The animals were given orally once daily aqueous solution containing $144 \mathrm{mg} / \mathrm{kg}$ body weight of $M$. oleifera from the first day till 30 days and from the first day of the experiment six equal intraperitoneal (IP) injections of ADR (each containing $3 \mathrm{mg} / \mathrm{kg}$ b.wt.) over a period of 19 days, with a total cumulative dosage of $18 \mathrm{mg} / \mathrm{kg}$ body weight. ${ }^{\text {th }}$ Group: MOR then ADR group: The animals were given orally once daily aqueous solution containing $144 \mathrm{mg} / \mathrm{kg}$ body weight of M. oleifera from the first day till 30 days and from day 11 of the experiment six equal intraperitoneal (IP) injections of ADR (each containing $3 \mathrm{mg} / \mathrm{kg}$ b.wt.) over a period of 19 days, with a total cumulative dosage of $18 \mathrm{mg} / \mathrm{kg}$ body weight. Animals were weighed and sacrificed by decapitation $48 \mathrm{~h}$ after the last treatment. 


\section{Studied parameters:}

\section{Weight:}

Animal's weights were measured from the start weight in the zero days, after each Adriamycin dose and Moringa dose and at the last day of the experiment to evaluate the body weight changes. Also, the animal mortality and any clinical toxicity symptom were recorded.

\section{Hematological and Biochemical analysis:}

After overnight fasting blood was collected from each rat by the retro orbital plexus method and collected on heparinized tubes for estimation of Hemoglobin $(\mathrm{Hb})$, Hematocrit (HCT) percentage, Red blood corpuscles (RBC), White blood cells (WBC) count, and Platelets (PLT) count by counter. Also blood serum samples are collected on serum-separating tubes and serum was separated by centrifugation to estimate Alanine aminotransferase (ALT), Aspartate aminotransferase (AST), serum Creatinine and serum Urea by their kits which obtained from Ran dox, Egypt.

\section{HISTOLOGICAL PREPARATION FOR LIGHT MICROSCOPY (PARAFFIN SECTIONS):}

The animals were sacrificed by cervical dislocation. The liver and kidneys were removed and cutting into small pieces. The specimens were fixed in $10 \%$ neutral formalin solution. After fixation, specimens were dehydrated in ascending series of ethyl alcohol 70, 80, 90 and 96\% for 20 minutes each, then in two changes of absolute ethyl alcohol for 30 minutes each. Tissues were cleared in xylol for 20 minutes (two changes) then impregnated in wax paraplast (three changes) at $60{ }^{\circ} \mathrm{C}$ for three hours and embedded in wax paraplast forming paraffin tissue blocks. Sections 4 to $5 \mu \mathrm{m}$ thick were prepared and stained according to the following histological methods then stained with hematoxylin \& eosin $\left({ }^{\mathbf{1 6}}\right)$.

\section{Statistical Analysis}

The results were statistically analyzed using analysis of variance (F-test) followed by Duncan's multiple range test to determine differences in means using Statistical Analysis Systems, Version 6.2 (SAS, 2000) $\left({ }^{17}\right)$. The paper has been approved by scientific and ethical committee of Zoology Department, Faculty of Science in University of Fayoum 2009.

\section{RESULTS AND DISCUSSION}

\section{Short toxicity symptoms \& mortality rate in treated groups.}

Animals that injected intraperitoneal with ADR showed clinical toxicity symptoms and signs starting from the second day and also after receiving other doses such as: nervous, loss of appetite, diarrhea, nausea, vomiting, general weakness, brittleness of skin hair and nails, then hair loss. At the end of experiment; the eye redness and ascites were observed. Results of the 
present study revealed that the morbidity and the mortality percent among different studied treated animal groups with the following order ADR (63\%) > ADR + MOR (37\%) > MOR / $\operatorname{ADR}(25 \%)>\mathrm{MOR}+\operatorname{ADR}(10 \%)$.

\section{Body weight changes.}

The body weight in Control (untreated) and Moringa groups showed noticeable increase as the period extended (Table 1). The body weights were recorded as (the mean \pm stander main error) at first day of the experiment and at the end of the experiment. Means with the same letter for each parameter are not significantly different, otherwise they do by (SAS, 2000). Animals treated with ADR over 19 days showed a highly significant decrease in their body weight $(\mathrm{P}<$ 0.01 ) by $-28.7 \mathrm{~g}$ in ADR group with percentage $-18.9 \%$ in comparison with control group (Table 1). On the other hand, there was a marked improvement of body weight change after treatment with Moringa (MOR+ADR, MOR/ADR and ADR + MOR) $(\mathrm{P}<0.05)$ by $(2.0,-8.3$ and $-18.0 \mathrm{~g}$ ) caused a non-significant decrease in the body weight of rat when compared with ADR group but still less than control group. The decrease in body weight among treated groups with the order, ADR > ADR+MOR > MOR/ADR > MOR+ADR tested groups.

\section{Blood Analysis}

\section{Serum Transaminases (ALT AND AST)}

There were differences in the hepatic enzyme activity (ALT and AST) among the different treated groups. Figure 8 showed the effect of different treatments on serum ALT and AST activity. Non-significant difference in serum ALT and AST activity between rat treated with Moringa group in comparison to control group. In contrast, animals treated with ADR showed a highly significant increase in serum ALT and AST activity comparing with the control $(\mathrm{P}<0.01)$. On the other hand, animals treated with ADR and Moringa revealed a significant decrease $(\mathrm{P}<0.05)$ in ALT and AST activity comparing with ADR group. Also the ALT and AST showed highly significant increase in ADR injected groups in the following groups with order $\mathrm{ADR}>\mathrm{ADR}+\mathrm{MOR}>\mathrm{MOR} / \mathrm{ADR}>\mathrm{MOR}+\mathrm{ADR}$ (Table 1).

\section{Serum Creatinine and Urea.}

Highly significant elevation $(\mathrm{P}<0.01)$ in serum creatinine in rats injected with ADR groups when compared to control and Moringa groups while animals in Moringa treated groups showed a significant increased $(\mathrm{P}<0.05)$ in the following order ADR+MOR > MOR/ADR > MOR+ADR. The most group that is close to control and Moringa groups is MOR+ADR group (Table 1). The serum urea values showed highly significant elevation in ADR group when compared to Moringa group that showed normal values as control group and increased in the following groups with order ADR+MOR > MOR/ADR > MOR+ADR.

\section{Hematological Analysis}


The $\mathrm{Hb}$ content, $\mathrm{HCT}$, RBCs count, $\mathrm{MCV}, \mathrm{MCH}$ and $\mathrm{MCHC}$ showed normal values in Moringa group as control group. A significance decrease in each $(\mathrm{Hb})$ content, (HCT) percentage, RBCs count and their derivative parameters ( $\mathrm{MCH} \& \mathrm{MCHC}$ ), while the $(\mathrm{MCV})$ value recorded the highest value in ADR treated group when compared with control. On the other hand, in Moringa treated groups (MOR+ADR, MOR/ADR and ADR+MOR), the values of (Hb), (HCT\%), (RBCs) count, (MCV), $(\mathrm{MCH})$ and $(\mathrm{MCHC})$ are elevated than ADR group but still little than control groups (Table 2). The WBCs and platelets count, were highly significant decrease in ADR, ADR+MOR when compared to control and Moringa groups. There is a nonsignificant change in the WBCs and platelets counts values in both MOR+ADR and MOR/ADR groups where they are less than the control and more than the values of others ADR group.

\section{Histopathological Observations of the Liver}

\section{Control Group and Moringa Group.}

There were no histological differences between Moringa and control ones, so the term control is applicable for both groups. The structural unit of the liver is the hepatic lobule which is made up of radiating strands of cells forming a network around a central vein. The liver cell strands are alternating with narrow blood sinusoids that also radially extending along the liver lobules, converging inwards to form the central veins. The hepatic sinusoids are narrow blood spaces with irregular boundaries composed of only a single layer of fenestrated endothelial cells, in addition to kupffer cells. The hepatic cells or hepatocytes are polyhedral in shape with a relatively large sizes and a noticeable granular cytoplasm. Each cell is embodying a prominent centrally located nucleus with one or two nucleoli (Plate I A-B).

\section{ADR Treated Group.}

Many histopathological alterations include loss of the liver architecture, the normal arrangement of the hepatocytes wasn't easily recognized and some hepatic strands were dissociated. The central vein and blood sinusoids were congested, dilated and surrounded with mononuclear leucocytic inflammatory cells. Also, some nuclei were swollen with clumped chromatin at their periphery; others were darkly stained or pyknotic with irregular nuclear outlines. Few hepatocytes appeared to have nuclei with signs of karyorrhexis and karyolysis. Most of the hepatocytes appeared with severe cytoplasmic vacuolization which is so extensive to the extent that only a very limited portion of it was left (Plate IC1-2). The studied liver sections showed higher tendency for loss of hepatic tissue structural pattern and fibrosis. Also, groups of degenerated and necrotic hepatocytes could be seen in different areas of the liver 
tissue. Numerous hypertrophied and darkly stained Kupffer cells were also seen in numbers more than those of the control (Plate I C3-4).

\section{ADR then MOR Group:}

Nearly the same histopathological observations seen in the ADR group as thickened wall, dilated and congested portal vein with periportal fibrosis and many pyknotic nuclei. Large degenerated area, with mononuclear leucocytes infiltration, dilated and congested portal vein, hyperplasia of the cells of bile ductules, Hypertrophied and darkly stained Kupffer cells. Note the presence of large necrotic area and marked periportal fibrosis (Plate I D).

\section{ADR and MOR Group:}

The repairing effects-up to certain limits were noticed; decrease in the blood vessels congestion, leucocytic infiltrations and few number of hepatocyte still appeared with cytoplasmic vacuolization and pyknotic nuclei was recorded with Moringa treatment. Kupffer and endothelial cells were hypertrophied with darkly stained nuclei. Note congested portal vein, large degenerated area, hyperplasia of the cells of bile ductules are present. (Plate I E).

\section{MOR Then ADR Group:}

Sections in the liver showing nearly more or less the normal histological architecture, normal central vein with slightly dilated sinusoid and very few kupffer cells, except some hepatocytes with vacuolated cytoplasm and others are some hepatocytes are binucleated (Plate I F1-2).

\section{Histopathological Observations of The Kidney}

Animals administered Moringa showed the same normal histological observations as in the kidney of control animals. The kidney is a bean-shaped organ, divided morphologically into an outer cortex and inner medulla. Bowman capsule consists of external parietal layer and internal visceral layer envelops the capillaries of the glomerulus, both layers are separated by a distinct space known as urinary space. The parietal layer of Bowman's capsule is continuous with the beginning of the proximal convoluted tubules. Here, the shape of the lining cells change from simple squamous in parietal layer to simple cuboidal or low columnar cells with a brush border in the proximal convoluted tubules (PT). These cells have acidophilic cytoplasm and exhibit brush borders at their apices and so the tubule lumens appear narrow. The nuclei of these cells are spherical and centrally located. The distal convoluted tubules (DT) have wider lumen and lined with simple cuboidal epithelia with no brush border (Plate II A-B).

ADR Treated Group. 
Examination of kidney cortex of rats injected with ADR exhibited severe and virtually complete epithelial cell damage and desquamation. Abnormal structure of glomeruli, such as lobed, degree of degeneration, splitting, separation or shrinkage of some glomeruli forming widen and irregular urinary space. Complete disappearance of some others, glomerular debris with ruptured Bowman's capsule lead to formation focal area of necrosis surrounded by inflammatory cells infiltration. Also, renal tubules showed desquamation, necrosis, fibrosis dilation with flattening epithelium causing disruption in the artchicture of the kidney. The epithelial cells were vacuolated with pyknotic nuclei and destructed near their brush borders. However, the degenerated epithelial cells were sloughed as fragments and expelled into the lumen of the renal tubules. Therefore; necrotic debris was frequent in the tubule lumens as hyaline cast (Plate II C1-3).

\section{ADR then MOR Group:}

Section of kidney tissues obtained from rat treated with Moringa and co-injected by ADR showed the same pathological changes reported in the previous group. The glomeruli appeared slightly swollen and the urinary space of Bowman's corpuscles remain irregular and wider than the normal. There is a sever degenerative changes in the cortex tubules. Also, slight degenerative changes were seen in some renal tubule as hyaline cast and exfoliated nuclei in their lumen. Note the presence of some darkly stained pyknotic nuclei in the epithelium of renal tubules (Plate II D1-2).

\section{ADR / MOR Group:}

The renal corpuscles still with irregular urinary spaces and lobed or ruptured glomeruli with erythrocytes. Few number of renal tubules regained their normal appearance with normal cytoplasm and basophillic centrally located nuclei. Many histopathological alterations were observed in the other tubules such as dilatation of both proximal and distal tubules with many exfolated cells and casts in their lumens. Proximal cells lose their brush borders and have pyknotic nuclei. Note a probable large liquefied necrotic area and fibrosis (Plate II E).

\section{MOR Then ADR Group:}

Marked improvements in the Malpighian corpuscle and the renal tubules than the $4^{\text {th }}$ and the $5^{\text {th }}$ groups that make the cortex appears more or less with normal histological structure as in the control and Moringa groups. Normal histological structure of Malpighian corpuscles with its normal glomeruli and some little wider space in few corpuscles. The PT and DT approximately regained their normal structure with narrow and wide lumens respectively (Plate II F). 
Table 1: Body weight gain (g), body weight gain percentage serum ALT, AST, creatinine and urea of male albino rats treated with moringa as antioxidant against side effects of adriamycin.

\begin{tabular}{|c|c|c|c|c|c|c|}
\hline Studied Treatments & $\begin{array}{l}\text { Body Weight } \\
\text { gain }(\mathrm{g})\end{array}$ & $\begin{array}{l}\text { Body weight } \\
\text { gain percentage } \\
(\%)\end{array}$ & $\operatorname{ALT}(\mathbf{u} / \mathbf{l})$ & $\operatorname{AST}(\mathbf{u} / \mathbf{l})$ & $\begin{array}{l}\text { Creatinine } \\
(\mathrm{mg} / 100 \mathrm{ml})\end{array}$ & $\begin{array}{l}\text { Urea } \\
(\mathrm{mg} / 100 \mathrm{ml})\end{array}$ \\
\hline G I: Control group rats & $12.0 \pm 0.25 \mathbf{A}$ & $6.1 \pm 0.025 \mathbf{A}$ & $62.83 \pm 0.82 \mathbf{E}$ & $150.3 \pm .38 \mathbf{D}$ & $0.81 \pm 0.007 \mathbf{D}$ & $29.76 \pm 1.02 \mathrm{D}$ \\
\hline G II: Rats treated with moringa for 30 days & $11.58 \pm 0.97 \mathbf{A}$ & $7.27 \pm 0.50 \mathbf{A}$ & $61.4 \pm 3.61 \mathbf{E}$ & $157.7 \pm .54 \mathbf{D}$ & $0.912 \pm .017 \mathbf{D}$ & $29.88 \pm 1.13 \mathrm{D}$ \\
\hline G III: Rats treated with adriamycin for 19 days & $-28.7 \pm 6.37 \mathbf{E}$ & $-18.9 \pm 0.574 \mathbf{E}$ & $137.3 \pm 5.3 \mathbf{A}$ & $284.7 \pm 0.1 \mathbf{A}$ & $2.87 \pm 0.04 \mathrm{~A}$ & $90.8 \pm 6.14 \mathbf{A}$ \\
\hline $\begin{array}{l}\text { G IV: Rats treated with adriamycin for } 19 \text { days then in } \\
\text { combination with moringa till the end of } 30 \text { days }\end{array}$ & $-18.0 \pm 4.27 \mathbf{D}$ & $-10.1 \pm 2.30 \mathbf{D}$ & $122 \pm 2.73 \mathbf{B}$ & $\begin{array}{l}265.1 \pm 10.2 \\
\text { A/B }\end{array}$ & $1.85 \pm 0.075 \mathbf{B}$ & $74.18 \pm 5.01 \mathrm{~B}$ \\
\hline $\begin{array}{l}\text { G V Rats treated with moringa in combination with } \\
\text { adriamycin for } 19 \text { days then with moringa till the end } \\
\text { of } 30 \text { days }\end{array}$ & $-8.3 \pm 1.26 \mathbf{C}$ & $-5.63 \pm 0.87 \mathbf{C}$ & $107.9 \pm 6.78 \mathrm{C}$ & $243 \pm 8.58 \mathbf{B}$ & $1.76 \pm 0.04 \mathbf{B}$ & $\begin{array}{l}62.42 \pm 6.57 \\
\mathbf{B} / \mathbf{C}\end{array}$ \\
\hline $\begin{array}{l}\text { G VI Rats treated with moringa from the first day then } \\
\text { in combination with adriamycin from eleventh day till } \\
\text { the end of } 30 \text { days }\end{array}$ & $2.0 \pm 0.3 \mathbf{B}$ & $1.65 \pm 0.32 \mathbf{B}$ & $91.32 \pm 2.47 \mathrm{D}$ & $195.7 \pm 6.49 \mathbf{C}$ & $1.46 \pm 0.03 \mathbf{C}$ & $51.28 \pm 2.93 \mathrm{C}$ \\
\hline F-values & $77^{* * *}$ & $92^{* * *}$ & $57 * *$ & $\mathbf{5 3 . 8}^{* *}$ & $333 * *$ & $30.5 * *$ \\
\hline
\end{tabular}

Data are represented as means of six samples \pm Sterr. Means within the same column, with the same letter for each parameter are not significantly different,

otherwise they do (SAS, 2000). ** Highly significant difference at $\mathrm{P} \leq 0.01$

Table 2: Blood parameters of male albino rats treated with moringa as antioxidant against side effects of adriamycin 


\begin{tabular}{|c|c|c|c|c|c|c|c|c|}
\hline Studied Treatments & $\begin{array}{l}\text { RBCs } \\
(\mathrm{X} \\
\left.\mathbf{1 0}^{6} / \mathbf{m m}^{3}\right)\end{array}$ & $\begin{array}{l}\text { Hb } \\
(\mathrm{g} / 100 \mathrm{ml})\end{array}$ & $\begin{array}{l}\text { Ht } \\
(\%)\end{array}$ & $\begin{array}{l}\text { MCV } \\
\left(\mu \mathbf{m}^{3} / \text { cell }\right)\end{array}$ & $\begin{array}{l}\text { MCH } \\
\text { (pg/cell) }\end{array}$ & $\begin{array}{l}\text { MCHC } \\
(\mathrm{g} / 100 \mathrm{ml})\end{array}$ & $\begin{array}{l}\text { Platelets } \\
\left(\mathrm{X} \mathrm{10}^{\mathbf{3}} / \mathbf{m m}^{\mathbf{3}}\right)\end{array}$ & $\begin{array}{l}\text { WBCs } \\
\left(\text { X 10 }^{3} / \mathbf{m m}^{3}\right)\end{array}$ \\
\hline Group I Control group rats & $\begin{array}{l}8.42 \\
\pm 0.34 \\
\mathrm{~A}\end{array}$ & $\begin{array}{l}11.40 \\
\pm 0.20 \\
\mathrm{~A}\end{array}$ & $\begin{array}{l}50.67 \\
\pm 2.74 \\
\mathrm{~A}\end{array}$ & $\begin{array}{l}59.97 \\
\pm 0.88 \\
\mathrm{C} / \mathrm{D}\end{array}$ & $\begin{array}{l}13.53 \\
\pm 0.31 \\
\mathrm{~B}\end{array}$ & $\begin{array}{l}22.67 \\
\pm 0.84 \\
\mathrm{~A} / \mathrm{B}\end{array}$ & $\begin{array}{l}435 \\
\pm 17.3 \\
\mathrm{~B}\end{array}$ & $\begin{array}{l}11.0 \\
\pm 0.07 \\
\mathrm{~A}\end{array}$ \\
\hline Group II Rats treated with moringa for 30 days & $\begin{array}{l}8.39 \\
\pm 0.20 \\
\text { A }\end{array}$ & $\begin{array}{l}11.27 \\
\pm 0.01 \\
\mathrm{~A}\end{array}$ & $\begin{array}{l}49.6 \\
\pm 1.54 \\
\mathrm{~A}\end{array}$ & $\begin{array}{l}59.07 \\
\pm 0.60 \\
\mathrm{C} / \mathrm{D} \\
\end{array}$ & $\begin{array}{l}13.48 \\
\pm 0.21 \\
\mathrm{~B}\end{array}$ & $\begin{array}{l}22.82 \\
\pm 0.49 \\
\mathrm{~A} / \mathrm{B}\end{array}$ & $\begin{array}{l}501 \\
\pm 4.15 \\
\mathrm{~A}\end{array}$ & $\begin{array}{l}11.07 \\
\pm 0.32 \\
\mathrm{~A}\end{array}$ \\
\hline Group III Rats treated with ADR for 19 days & $\begin{array}{l}4.99 \\
\pm 0.07 \\
\mathrm{C}\end{array}$ & $\begin{array}{l}8.04 \\
\pm 0.24 \\
D\end{array}$ & $\begin{array}{l}37.2 \\
\pm 1.11 \\
\mathrm{C}\end{array}$ & $\begin{array}{l}74.3 \\
\pm 1.22 \\
\text { A }\end{array}$ & $\begin{array}{l}16.13 \\
\pm 0.53 \\
\text { A }\end{array}$ & $\begin{array}{l}21.73 \\
\pm 0.93 \\
\text { B }\end{array}$ & $\begin{array}{l}217 \\
\pm 8.76 \\
\mathrm{E}\end{array}$ & $\begin{array}{l}6.74 \\
\pm 0.197 \\
D\end{array}$ \\
\hline $\begin{array}{l}\text { Group IV Rats treated with ADR for } 19 \text { days then } \\
\text { in combination with moringa till the end of } 30 \text { days }\end{array}$ & $\begin{array}{l}6.33 \\
\pm 0.27 \\
\mathrm{~B}\end{array}$ & $\begin{array}{l}9.82 \\
\pm 0.30 \\
\mathrm{~B} / \mathrm{C}\end{array}$ & $\begin{array}{l}40.5 \\
\pm 0.77 \\
\mathrm{~B} / \mathrm{C}\end{array}$ & $\begin{array}{l}64.38 \\
\pm 2.03 \\
\mathrm{~B}\end{array}$ & $\begin{array}{l}15.6 \\
\pm 0.53 \\
\text { A }\end{array}$ & $\begin{array}{l}24.2 \\
\pm 0.32 \\
\mathrm{~A}\end{array}$ & $\begin{array}{l}291 \\
\pm 27 \\
\mathrm{D}\end{array}$ & $\begin{array}{l}8.31 \\
\pm 0.23 \\
\mathrm{C}\end{array}$ \\
\hline $\begin{array}{l}\text { Group V Rats treated with moringa in combination } \\
\text { with ADR for } 19 \text { days then with moringa till the end } \\
\text { of } 30 \text { days }\end{array}$ & $\begin{array}{l}6.49 \\
\pm 0.23 \\
\text { B }\end{array}$ & $\begin{array}{l}9.76 \\
\pm 0.37 \\
\mathrm{C}\end{array}$ & $\begin{array}{l}39.9 \\
\pm 1.08 \\
\mathrm{C}\end{array}$ & $\begin{array}{l}61.68 \\
\pm 1.14 \\
\mathrm{~B} / \mathrm{C} \\
\end{array}$ & $\begin{array}{l}15.03 \\
\pm 0.31 \\
\text { A }\end{array}$ & $\begin{array}{l}24.42 \\
\pm 0.27 \\
\text { A }\end{array}$ & $\begin{array}{l}364 \\
\pm 9.60 \\
C\end{array}$ & $\begin{array}{l}8.84 \\
\pm 0.17 \\
\mathrm{C}\end{array}$ \\
\hline $\begin{array}{l}\text { Group VI Rats treated with moringa from the first } \\
\text { day then in combination with ADR in from eleventh } \\
\text { day till the end of } 30 \text { days }\end{array}$ & $\begin{array}{l}7.84 \\
\pm 0.22 \\
\text { A }\end{array}$ & $\begin{array}{l}10.51 \\
\pm 0.12 \\
B\end{array}$ & $\begin{array}{l}44.68 \\
\pm 0.82 \\
B\end{array}$ & $\begin{array}{l}57.12 \\
\pm 0.58 \\
D\end{array}$ & $\begin{array}{l}13.47 \\
\pm 0.38 \\
\mathrm{~B}\end{array}$ & $\begin{array}{l}23.57 \\
\pm 0.43 \\
\mathrm{~A} / \mathrm{B}\end{array}$ & $\begin{array}{l}527 \\
\pm 38 \\
\text { A }\end{array}$ & $\begin{array}{l}10.33 \\
\pm 0.20 \\
B\end{array}$ \\
\hline F-values & $33.9^{* *}$ & $25.8^{* *}$ & $13.3^{* *}$ & $27^{* *}$ & $9.05^{* *}$ & $2.84^{* *}$ & 33.04** & 65.99** \\
\hline
\end{tabular}

Data are represented as means ofsix samples \pm Sterr.

Means within the same column, with the same letter for each parameter are not significantly different, otherwise they do (SAS, 2000).

** Highly significant difference at $\mathrm{P} \leq 0.01$ 


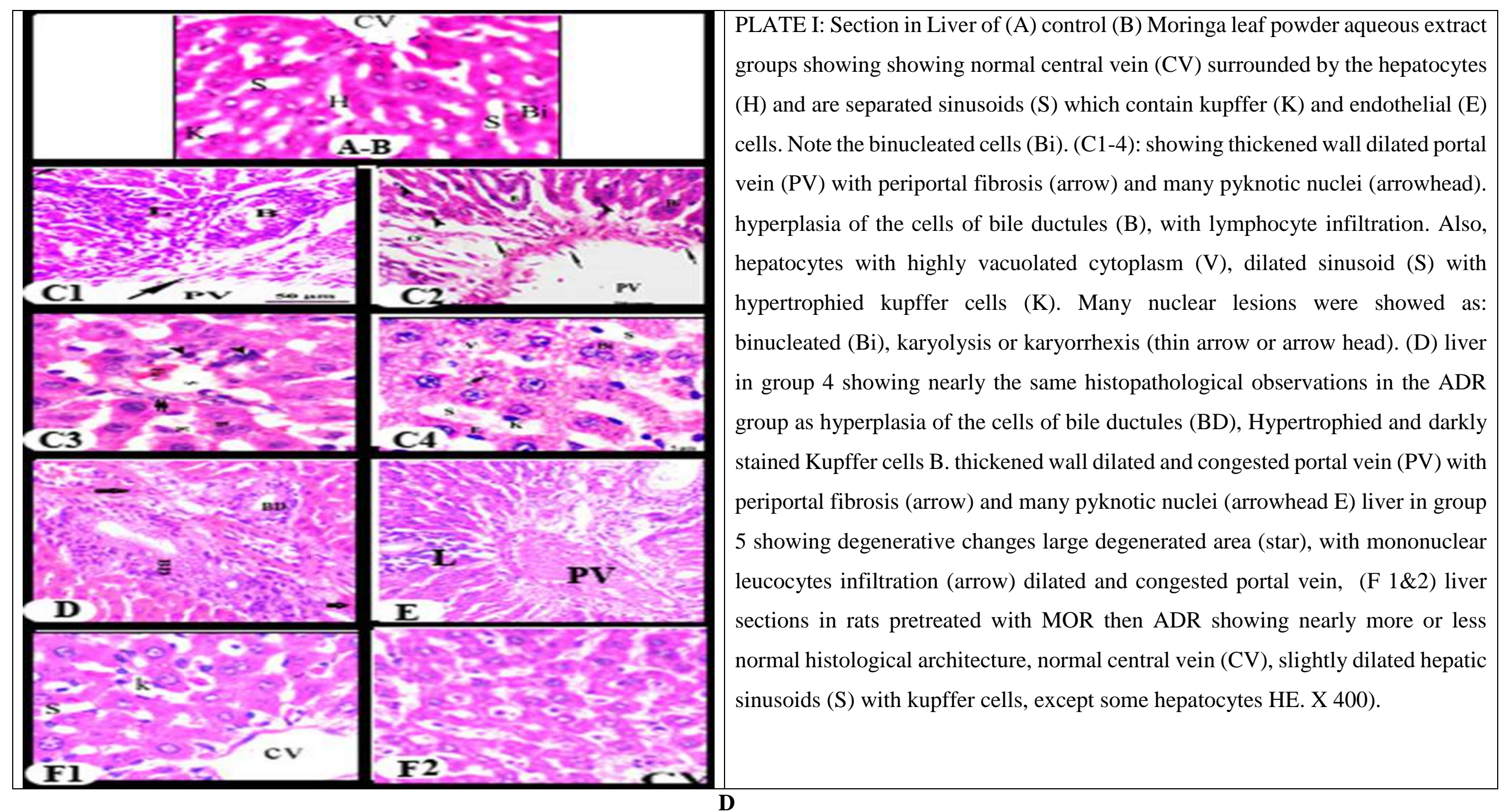




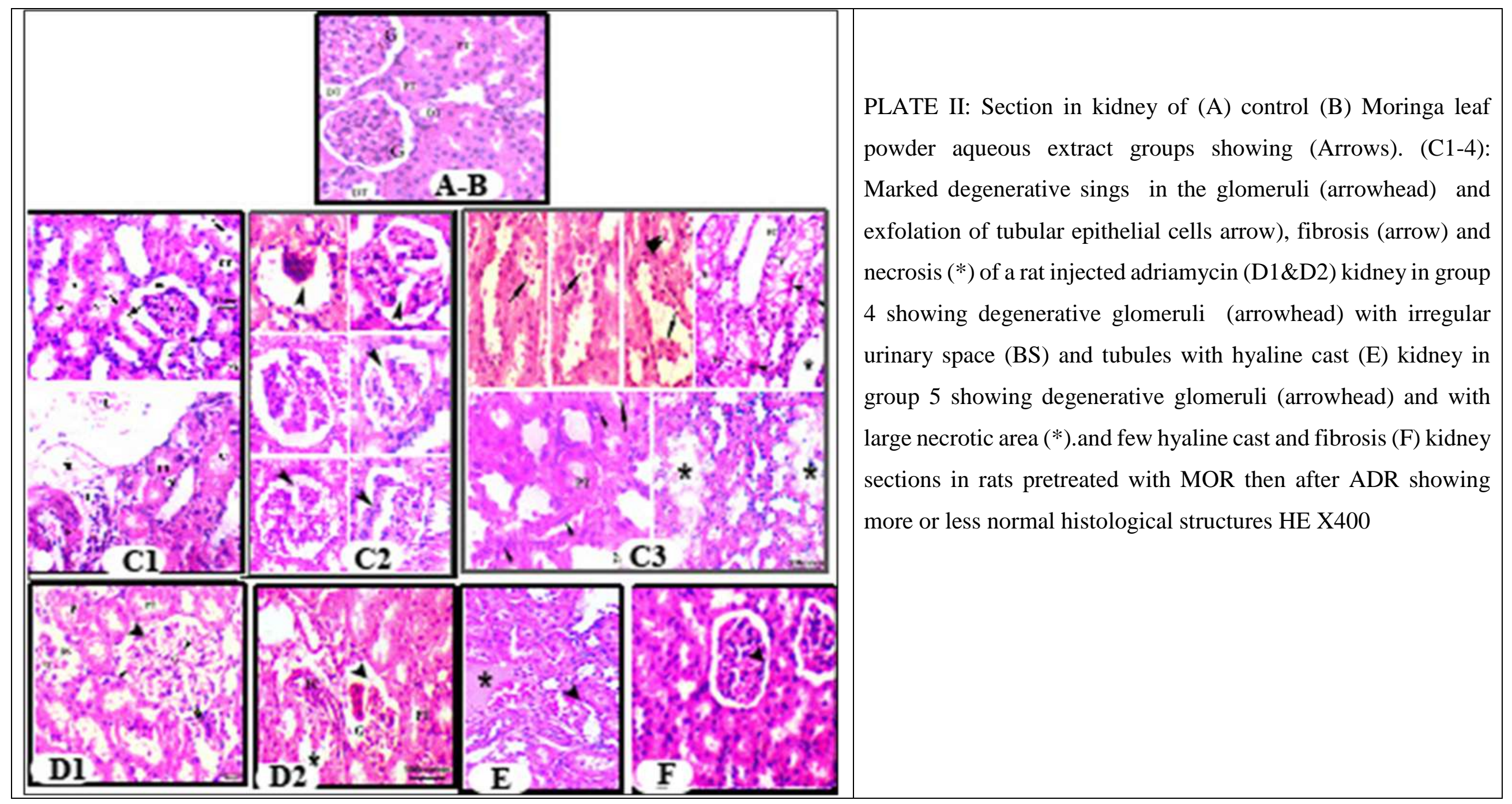




\section{DISCUSSION}

Anticancer drugs are widely used against variety of human tumors. They generate acceptable outcome in chemotherapy of some types of cancers, they also exhibit severe toxicity and undesirable side effects $\left({ }^{\mathbf{1 8}}\right)$. Since Adriamycin (doxorubicin) remains one of the most effective and widely used chemotherapeutic drugs ever developed, with high anti-neoplastic activity to breast cancer, aggressive lymphomas, childhood solid tumors and soft tissue sarcomas $\left({ }^{\mathbf{1 9 , 2 0}}\right)$. Its clinical use is limited because of several side effects like cardiotoxicity, nephrotoxicity and hepatotoxicity $\mathbf{( 2 1}^{\mathbf{2 1}}$. Doxorubicin (DOX) is considered as a backbone in several chemotherapeutic regimens. Nevertheless, the reported systemic toxicity usually hampers its broad application ${ }^{(22}$ ). Natural products, including pure compounds, herb extracts and composite formula, have been reported to effectively reduce the side effects induced by chemotherapy $\left({ }^{\mathbf{2 3}}\right)$. The use of natural products as an alternative to conventional treatment in healing and treatment of various diseases has been on the rise in the last few decades. Medicinal plants serve as therapeutic alternatives, safer choices, or in some cases, as the only effective treatment. Therefore, a strategy to diminish the side effects of chemotherapy drugs with preservation of their chemotherapeutic efficacy is needed. It was suggested that the combination of drug delivery together with potent antioxidant agents may be an appropriate way to reduce the side effects of chemotherapy drugs $\left({ }^{24,25}\right)$. Moringa oleifera Lam. is a highly valued plant, distributed in many countries and best known as excellent source of nutrition and a natural energy booster. Various parts of this plant such as the leaves, roots, seed, bark, fruit, flowers and immature pods act as cardiac and circulatory stimulants, antipyretic, antitumor, anti-inflammatory, antiepileptic, diuretic, antiulcer, antispasmodic antihypertensive, cholesterol lowering, antidiabetic, antioxidant, antibacterial, hepatoprotective, and antifungal activities $\left({ }^{9}\right)$. This study is directed to investigate the protective effect of Moringa against ADR-induced hepatotoxicity and nephrotoxicity from mortality rate, body weight changes, biochemical, hematological and histopathological points of view.

\section{Short Term Toxicity (Clinical Signs and Symptoms)}

The experimental control groups rats and that pretreated with moriga did not reveal any characteristic symptoms throughout the experiment period. On the second day of experiment, rats in other ADR (IP) injected groups (3, 4 \& 5) showed general toxicity symptoms and clinical signs of deterioration such as: nervous, loss of appetite, diarrhea, nausea, vomiting, general weakness, brittleness of skin hair and nails, then hair loss were observed. At the end of experiment; the eye redness and ascites (the accumulation of fluid in the peritoneal cavity causing abdominal swelling) were observed. This results are in agreement with ${ }^{(26}$ ) who found that 
when mice injected IP with ADR (six equal injections each containing $3 \mathrm{mg} / \mathrm{kg}$ ) over a period of 2 weeks, with a total cumulative dosage of $18 \mathrm{mg} / \mathrm{kg}$ body weight showed some toxicity symptoms and clinical signs from the second day and also after receiving other doses that resemble the symptoms appeared on rats such as decrease food and water intake, diarrhea, nervous, brittleness of skin hair and ascites in abdominal cavity were observed. Singal et $\boldsymbol{a l} .\left(^{5}\right)$ reported that, the acute side effects, which may develop within minutes after intravenous administration of the adrimaycin, are nausea, vomiting, alopecia, myelosuppression and arrhythmias. These effects are reversible and clinically manageable. The chronic side effects, that may develop several weeks or months after repetitive Adriamycin administration, include cardiovascular, hematopoietic suppression, stomatitis $\left({ }^{27}\right)$.

\section{Mortality Rate}

The morbidity and the mortality percent among treated groups with the order ADR $>\mathrm{ADR}$ then $\mathrm{MOR}>\mathrm{MOR}$ with $\mathrm{ADR}>\mathrm{MOR}$ then $\mathrm{ADR}>\mathrm{MOR}>$ control. In agreement with the recorded results, morbidity was proportionally higher in rats treated with cumulative doses of doxorubicin alone in contrast to rats treated with both doxorubicin and $\alpha$-lipoic acid $\left.{ }^{(28}\right)$. Moreover, highest morbidity and the mortality percent among ADR treated groups than the other treated groups in which garlic treatment entered with Adriamycin (26).

\section{Body Weight}

The present study revealed an increase in rats' body weight of untreated and Moringa treated control groups. Our results in agreement with, Bais et al. $\left({ }^{29}\right)$ results that indicate significant attenuation in the body weight without any change in the feed intake in rats treated with Moringa oleifera. Moreover, Hassan \& Aya ( $\left.{ }^{\mathbf{3 0}}\right)$ found that rabbits administrated orally with aqueous solutions of $M$. oleifera leaves with different doses $(2,4,6,8$ gm of the powdered $M$. oleifera leaves diluted in $10 \mathrm{mls}$ of distilled water each) for the period of 2 weeks have a potential for use in diets to increase the weight of rabbits.

Body weight considered an indicator of general health in models of chemotherapy-induced fatigue $\left({ }^{31}\right)$. The weight loss in ADR group could be attributed to the diminished food intake that might be the result of central (induction of chemotherapy trigger zone or vomiting center) and/or peripheral (stomatitis and gastroenteritis) mechanisms $\left({ }^{\mathbf{3 2}}\right)$. Moreover, Saber et al. ${ }^{(33}$ ) reported that the rats treated with $\mathrm{ADR}$ at a dose level of $2 \mathrm{mg} / \mathrm{kg}$ body weight in sterile saline, once per week for 6 weeks caused significant decrease in body weight of rats in comparison with control and others groups. Also, our data in parallel with the results of Kalender et al. ${ }^{(34}$ ) and Yusuf et al. $\left({ }^{\mathbf{3 5}}\right)$ they stated that any antibiotics such as ADR and idarubicin cause weight 
loss and for this reason, their prolonged use and over dosage cause death. Moreover, treatments with $0.2 \mathrm{mg} / \mathrm{kg}$ and $1 \mathrm{mg} / \mathrm{kg}$ doses of doxorubicin caused inhibition in the percentage of weight gain as compared to controls $(P<0.05)$ indicating retardation in growth. The reduction in body weight of the rats correlate with the decreased food intake observed during the experimental period $\left({ }^{36}\right)$. In response to Moringa, rats in the $4^{\text {th }}$ and the $5^{\text {th }}$ groups showed a significant reduction $(\mathrm{p}<0.05)$ in their body weights but less than the marked reduction in the $3^{\text {rd }}$ group (ADR injected rats). This indicate that rats that post treated with Moringa and at the same time of the ADR injection from the first day could not protect rats from weight loss. Our results are in agreement with Ekor $\boldsymbol{e t}$ al. $\left(^{(37}\right)$ who found that a single injection of rats with Cisplatin (IP) with a dose of $7.5 \mathrm{mg} / \mathrm{kg}$ significantly decrease the rat's body weight by $21.9 \%$ and treatment with both methanolic and aqueous extract of Moringa did not significantly prevent this weight loss after 5 days of daily administration. In contrast, rats in the $6^{\text {th }}$ group showed a little improvement in their body weights and the percentages of weight gain.

\section{Hematological changes:}

The most significant toxicity of Adriamycin was bone marrow depression. Usually in cancer chemotherapy the major problem is anemia due to reduction in $\operatorname{RBC}\left({ }^{\mathbf{3 8}}\right)$. The highly significant decrease in the studied blood parameters of ADR treated rats than that of control groups is accompanied by an increase in the derivative blood parameter $(\mathrm{MCV})$. The highest $\mathrm{MCV}$ value may due to the macrocytosis that's occur because of Adriamycin myelosupression. On the other hand, MOR pretreated groups showed ameliorative effect on hematological parameters, but they still less than the control group and show better results than the $4^{\text {th }}$ and the $5^{\text {th }}$ groups. Our results are in agreement with ${ }^{(39}$ ) who found that no significant changes observed on the haematological parameters of normal and immunosuppressed mice after treating with the ethanolic extract of $M$. olifera. Moreover, there was a hypochromic microcytic anemia has been reported to be the result of decreased of bone marrow activity in cases of lead acetate solution toxicity $(1000 \mathrm{mg} / \mathrm{kg})$ by gavage daily for 7 days in both animals and humans. In contrast, Moringa at $1000 \mathrm{mg} / \mathrm{kg}$ daily have ameliorative action where it showed a more rapid improvement (at $14^{\text {th }}$ day) in $\mathrm{MCV}$ and $\mathrm{MCH}$ parameters no adverse effects have been noted with long term consumption, it may provide a safe and effective preventative measure against lead toxicity $\left({ }^{40}\right)$. The WBCs and platelets count, were highly significant decreasing in ADR treated groups when compared to control, Moringa and $6^{\text {th }}$ groups. Weiss, $\left({ }^{41}\right)$ showed that doxorubicin treatment caused blood count suppression. Single dose of adriamycin (15 mg/kg) caused leukopenia, decreased number of WBCs, indicated that blood toxicity of adriamycin $\left({ }^{\mathbf{4 2}}\right)$. Also, Gupta et al. $\left({ }^{39}\right)$ found that there was a 
significant reduction in WBCs count and neutrophils percentage of mice when treated with cyclophosphamide, but the restoration of these parameters was observed after combined treatment of with cyclophosphamide and the ethanolic extract of M. Olifera. Moreover, Adedapo et al. $\left({ }^{\mathbf{4 3}}\right)$ studies showed that the aqueous extract from the leaves of Moringa oleifera particularly the 400 and 800 $\mathrm{mg} / \mathrm{kg}$ doses caused significant increase in the level of white blood cell counts and its differentials.

\section{ADR Induced Hepatotoxicity}

\section{Biochemical Assessment (ALT \& AST)}

In the current study, hepatic insult was chosen as it affects not only liver function in $40 \%$ of patients receiving ADR (as one of the potentially affected organs) ${ }^{\mathbf{4 4}}$ ), but also it may affect ADR metabolism and clearance as the liver is the main organ concerned with ADR detoxification. Extensive investigations have been conducted on the hepatotoxicity and kidney toxicity as well as general organ toxicity of Adriamycin $\left({ }^{\mathbf{3 3}}\right)$. Such hepatic toxicity could be due to oxidative stress, apoptosis and interference with the electron transport chain $\left({ }^{\mathbf{4 5}}\right)$. Over the years, many studies discussed different strategies to overcome DOX-mediated toxicity, however no ideal agent is yet recommended. Although dexrazoxane was the only FDA approved agent against DOX toxicity, it is rarely used clinically due to its reported side effects including decreased DOX efficacy and increasing the incidence of acute myeloid leukemia and myelodysplastic syndrome $\left({ }^{\mathbf{4 6}, 47}\right)$.

Aspartate aminotransferase (AST) and alanine aminotransferase (ALT) are liver-specific variables which give an indication of hepatotoxicity. These enzymes have a wide distribution in all body tissue damages and present in small quantities in the plasma as a consequence of normal tissue destruction and subsequent enzyme release $\left({ }^{48-50}\right)$. Serum ALT and AST are useful indicators of hepatocyte integrity as both are normally located intracellular. AST is widely distributed in the body organs so it is worth noting that ALT is considered the most liver-specific of the transaminases $\left.{ }^{(51}\right)$.

Animals treated with ADR only and those of $4^{\text {th }}$ and $5^{\text {th }}$ groups showed a highly significant increase in serum ALT and AST activity comparing with the control $(\mathrm{P}<0.01)$. Several investigators have been reported that ADR treatment lead to hepatotoxicity characterized by elevation in the sensitive indicators of liver injury serum AST and ALT ( $\left.{ }^{\mathbf{5 2}-54}\right)$. Also, Injac et al. $\left({ }^{\mathbf{5 5}}\right)$ showed that treatment with Adriamycin caused significant changes in the serum levels of ALT, AST, LDH and alpha-hydroxybutyrate dehydrogenase (alpha- HBDH). Also, DOX injection $(20 \mathrm{mg} / \mathrm{kg})$ increased serum ALT level twice normal in mice $\left({ }^{56}\right)$ or $(30 \mathrm{mg} / \mathrm{kg}$ body weight) injected intraperitoneally in a single dose also elevates these liver enzymes Mete $\boldsymbol{e t}$ al. $\left.{ }^{(57}\right)$. Moreover, these results are parallel with the results of Ibrahim et al. (2018) who showed 
that ADR injection $(2.5 \mathrm{mg} / \mathrm{kg}$, IP injections thrice a week) caused significant elevation in rat liver transaminases (more than three folds in ALT and two folds in AST) which designate compromised cellular integrity. Therefore, the elevation in serum AST and ALT levels following ADR treatment in this study may represent acute hepatotoxicity. These enzymes may be leaked to blood stream due to peroxidative damage to the cell membrane of liver $\left({ }^{\mathbf{5 8}}\right)$ or due to hepatocytes injury may alters their transport function and membrane permeability, leading to leakage of enzymes from cells $\left({ }^{\mathbf{5 9}}\right)$. In addition, Kumar et al. $\left({ }^{\mathbf{6 0}}\right)$ showed that serum enzymes like AST, ALT, ALP and total bilirubin levels were significantly $(\mathrm{p}<0.01)$ decreased in rats treated with $M$. oleifera and Silymarin when compared to ethanol treated rats in both preventive and curative study indicating that $M$. oleifera and Silymarin administration make hepatoprotection from elevation of its enzymes and prevented the toxic effect of ethanol on the serum parameters in both models. Also, Adedapo et al. $\left({ }^{\mathbf{4 3}}\right)$ found significant decrease in the high levels of liver enzymes (ALT and AST) in rats that $800 \mathrm{mg} / \mathrm{kg}$ dose of M. oleifera. In our experiment we have found that the dose of Moringa (144 mg/kg/day) that used had make no changes in ALT and AST values and were very close to the control group.

On the other hand, animals in MOR pretreated group ( $6^{\text {th }}$ group $)$ revealed a significant decrease $(\mathrm{P}<0.05)$ in ALT and AST activity compared with other ADR groups and this indicates that pretreatment with Moringa may be provide a hepatoprotection against ADR toxicity, this also appear in the findings of Singh et al. $\left({ }^{61}\right)$ in rat treated with Moringa leaf extract $(100,200$ \& $400 \mathrm{mg} / \mathrm{kg})$ after intoxicated with carbon tetrachloride $\left(\mathrm{CCl}_{4}\right)$ at the dose level of $0.3 \mathrm{~mL} / \mathrm{kg}$ body weight/twice a week, intra-peritoneally for 60 days at $(p \leq 0.001)$. Also, the increase in ALT and AST activities following DOX administration was significantly prevented by preceded treatment by onion (Allium cepa) extract (ACE) ${ }^{(57}$ ). The antioxidant properties of different fractions of $M$. oleifera leave providing a biochemical rational for the antioxidant and chemoprotectant effects $\left({ }^{\mathbf{6 2}}\right)$. Co-administration of Moringa leaves as a food supplementation significantly reduced arsenic-induced elevation of ALP, AST and ALT activities. These results indicated that Moringa leaves had a protective effect on arsenic-induced liver injury and also Moringa leaves potentially inhibited the arsenic-induced elevation of serum urea levels $\left({ }^{63}\right)$. Hepatocytes are the likely targets of reactive oxygen species attack in the failing liver. It is conceivable that free radicals cause damage at their formation $\left({ }^{64}\right)$. It was also mentioned that ADR has persistent and irreversible toxic effects on hepatic tissue $\left.{ }^{\left({ }^{65}\right.}\right)$.

\section{Histopathological Alterations:}

The present study showed that examination of liver sections of control male albino rats and Moringa leaf powder aqueous extract treated groups showed normal histological structure of the liver which indicates that Moringa did not cause any toxic effects to the histological structure of the liver. Hepatocytes and central veins appeared normal, endothelial and Kupffer 
cells are also prominently stained, these observations showed that Moringa would not produce deleterious effect on the liver of the treated animals. Our findings are in agreement with Ghazal et al. $\left.{ }^{(66}\right)$ who indicated that Moringa leaf extract has no effect on the histology of the liver of the expermintal rats. In the other hand, different apoptotic figures were noticed among the hepatocytes in the form of; densely compacted batches of nuclear chromatin (pyknosis), nuclear fragments (karyorrhexis \& karyolysis), hypereosinophillic cytoplasm. Many apoptotic bodies were observed in the cytoplasm togegther with many vacoules. Also, necrotic areas were seen in the liver. These necrotic areas were surrounded by mononuclear cell infilitration in the liver sections of rats injected with adriamycin. Parallel with these results El-Sayyad $\boldsymbol{e t}$ al. $\left.{ }^{(36}\right)$ noticed similar histopathological abnormalities involved dissolution of hepatic cords, (empty vacuoles) aligned by strands of necrotic hepatocytes, presence of dense focal inflammatory cells or necrotic tissues. Also, perivascular round cell infiltration, associated with membrane changes of endothelial lining cells manifesting periportal fibrosis, marked degeneration of hepatic cords, increased incidence of vacuolar degeneration and apoptotic cell death. In addition, Lee $\boldsymbol{e t}$ al. $\left({ }^{\mathbf{5 9}}\right)$ reported that intraperitoneal injection of ADR $(10 \mathrm{mg} / \mathrm{kg})$ in rats revealed various structural changes in liver, characterized by hepatocyte degeneration/necrosis, congestion, sinusoidal dilatation, vacuolation of the cytoplasm, and inflammatory cell infiltration. Ballooning degeneration and vacuolar appearance of the hepatocytes which was attributed to the hydropic changes. Parallel with these results Mete $\boldsymbol{e t}$ al. $\left({ }^{57}\right)$ reported that, DOX (30mg/kg body weight) was injected intraperitoneally in a single dose induced hepatotoxicity and has been confirmed by its histopathological changes in the liver tissue such as degeneration and pleomorphism in hepatocytes, proliferation in bile duct, cytoplasmic eosinophilia., necrosis, congestion and thrombosis in central vein, and inflammation in portal space in liver tissue of a single dose of DOX-administered rats. In this respect, Rashid et al. ${ }^{(21)}$ reported that single i.p. injection of DOX (40mg/kg) caused significant structural damage to liver and kidney tissues of Wistar rats. Focal damage in hepatocytes, significant steatosis, and vascular damage were shown in the liver tissue after administration of DOX $\left({ }^{67}\right)$. Also, simillar histopathological observations were reported by Jaćević et al. ${ }^{(\mathbf{6 8})}$ in rats treated with DOX, who showed numerous alterations in the hepatic tissues and in the usual radial arrangements of the liver parenchyma. These alterations included moderate oedema and hyperemia in all sinusoidal spaces. Focal hemorrhages were localized primarily perivascularly, and partly in the periportal space of the hepatic lobule. Hypertrophic Kupffer's cells could be seen in the sinusoidal spaces. Almost all hepatocytes were oedematous with marked intracellular degeneration. Also, the majority of the blood vessels were dilated, with discontinued walls which are surrounded by accumulations of polymorphonuclear cells. 
The present study showed remarkable abundance of leucocytic infiltrations, blood vessels congestion, thickened wall of the dilated portal vein with priportal fibrosis and many pyknotic nuclei. Large degenerated area, dilated and congested portal vein, hyperplasia of the cells of bile ductules in the studied liver sections of ADR, ADR with MOR and ADR then MOR groups. Similar observations were obtained by Zhao et al., $\left({ }^{54}\right)$ and Gokcimen et al. $\left({ }^{65}\right)$ who reported that Adriamycin increased mononuclear cells infiltration, congestion of blood vessels and necrosis. Also, perivascular round cell infiltration, associated with membrane changes of the lining endothelial cells manifesting periportal fibrosis. Additionally, doxorubicin treatment showed higher tendency for liver fibrosis manifested by the presence of many spots of focal cellular granulomatous lesions after receiving doxorubicin at doses $(0.2 \mathrm{mg} / \mathrm{kg})$ and $(1 \mathrm{mg} / \mathrm{kg})$ for 20 days $\left({ }^{\mathbf{3 6}}\right)$.

Periportal leucocytic infiltration seen in the present study was similar to that observed by Ibrahim et al. ${ }^{(22}$ ) who referred to ROS formation through promoting cytokines IL-6 and IL-8 (the main modulators of hepatic inflammatory response). Doxorubicin-induced hepatotoxicity was associated with an oxidative stress status (imbalance in the normal metabolism of oxygen either due to the excessive production of reactive oxygen species (ROS) and/or a reduction in the antioxidants and sulfhydryl groups) $\left({ }^{69}\right)$. The addition of one electron to the quinone moiety of DOX leads to the formation of semiquinone form that regenerates the quinone form by reducing molecular oxygen to ROS. In turn, such ROS can generate both hydrogen peroxide $(\mathrm{H} 2 \mathrm{O} 2)$ and hydroxyl radicals $(\mathrm{OH})\left({ }^{57}\right)$. Vascular congestion was also explained to be due to cytokines induced vascular endothelial cells swelling and malfunctioning that might result in retention of blood elements in the space of Disse $\left(^{70}\right)$. Several binucleated hepatocytes were observed in the liver tissue which could be considered as a sign of the preserved regenerative power of hepatocytes compared to the mononuclear shift discerned in DOX group. Binucleated hepatocytes are more likely to undergo mitosis in case of liver injury by being more responsive to hepatocytes growth factors $\left(^{\mathbf{7 1}}\right)$. Moreover, the DOXinduced oxidative stress could increase the expression of endothelial growth factors and therefore, enhancing the mitotic activity of epithelial cells as those lining the bile ducts resulting in biliary hyperplasia and the associated inflammatory cellular infiltration $\left({ }^{57}, 22\right)$.

Here, rats treated with $\mathrm{ADR}$ and Moringa showed that the liver tissue acquired little improvement as decrease blood congestion and few leucocytic infiltrations comparing with other Adriamycin groups. But as depicted in the liver sections of 
rats pretreatment with Moringa then ADR (the $6^{\text {th }}$ group), the liver tissue was maintained near normal where hepatocytes showed granular acidophilic cytoplasm with central vesicular nuclei, some binucleated hepatocytes were frequently noticed denoting the safety of moringa at the given dose. In the same context, the application of Amifostine (a cytoprotective adjuvant used in cancer chemotherapy and radiotherapy) prior to DOX significantly attenuated the degenerative and vascular changes caused by this chemotherapeutic agent $\left.{ }^{\mathbf{6 8}}\right)$. Moreover, Rašković et al. $\left({ }^{72}\right)$ indicated that silymarin (antioxidant) could prevent damage of liver and heart tissue induced by doxorubicin administered every other day at a dose of 1.66 $\mathrm{mg} / \mathrm{kg}$ intraperitoneally for twelve days, the process of lipid peroxidation, was statistically significantly higher in group treated with doxorubicin, compared to the control and experimental groups (Silymarin and DOX-Silymarin). Additionally, the previous histopathological findings caused by DOX and reported by Mete et al. $\left({ }^{57}\right)$ were showed to be markedly prevented by Allium cepa extract (ACE) pretreatment, thereby highlighting its protective role in countering the oxidative cytotoxic injury inflicted by DOX. In another study, the repairing effects-up to certain limits were noticed since some hepatocytes still showed cytoplasmic vacuolization and pyknotic or karyolayzed nuclei. Kupffer cells and endothelial cells were hypertrophied and darkly stained. This indicated the effectiveness of garlic aqueous extract in decreasing Adriamycin hepatotoxicity $\left({ }^{73}\right)$. In this concern, Buraimoh et al. $\left({ }^{74}\right)$, showed that rats treated with $500 \mathrm{mg} / \mathrm{kg}$ body weight of the ethanolic extract of Moringa oleifera leaves on a daily dose for 10 days and they received $1 \mathrm{~g} / \mathrm{kg}$ (hepatotoxic dose) body weight of paracetamol on the $10^{\text {th }}$ day of the experiment, showed necrotic cells and wide sinusoidal spaces observed in the liver tissue might be due in part to the presence of chemical constituents which have hepatoprotective properties. Moreover, Kumar et al. $\left(^{(60}\right)$ reported degenerative changes in the rat liver after $\mathrm{CCl}_{4}$ treatment such as fatty degenerative changes with cytoplasmic free areas, congestion of sinusoids, pyknotic nuclei, necrosis and infiltration of polymorphonucleocytes. These alterations decreased or become absent after treatment with 100 or $200 \mathrm{mg} / \mathrm{kg}$ (60 days) of $M$. oleifera extract. The another suggested that this might be due to lower fat accumulation and re-establishment of the antioxidant defense system in the liver tissue through the antioxidant and hepatoprotective nature of $M$. oleifera leaves.

It was reported that antioxidans such as vitamins $\mathrm{A}, \mathrm{E}, \mathrm{C}$ as well berberine, resveratrol and wheat germ oil were widely investigated to assess their potential to mitigate DOX-imposed hepatotoxicity $\left({ }^{\mathbf{2 2}}\right)$. The pretreatment with Moringa may be protect and /or ameliorate the 
hepatotoxicity inuded by ADR injection. In the same manner, Mete et al. $\left({ }^{57}\right)$ found that the pretreatment with ACE protects against DOX-induced hepatotoxicity due to the antioxidant properties of ACE. Similarly Elesh $\left({ }^{\mathbf{7 3}}\right)$ revealed that galic aqueous extract provided an ameliorative effect against hepatotoxic effect of ADR in male mice.

Microscopic examination of kidney sections after ADR treatment revealed congested, atrophied, shrinkage or degenerated glomeruli with widen Bowman's space. Proximal and distal tubules showed degeneration, hyaline cast, interstitial hemorrhage and fibrosis. Similar observations were obtained by Okasora et al. (75) who stated that the lumina of tubules in the kidney tissues of subjects given Adriamycin were filled with an amorphous material which was observed in some tubules and El-Shitany et al. $\left(^{76}\right)$ reported that a single dose of ADR (10 $\left.\mathrm{mg} / \mathrm{kg}\right)$ produced proximal tubular degeneration and cast formation which characterized nephrotoxicity that was also manifested by increased plasma creatinine and urea levels. These findings are in accordance with our reported creatinine and BUN results after ADR treatment and with the findings of Mansour et al. $\left({ }^{77}\right)$, Saad et al. ${ }^{(78)}$ and Yilmaz et al. $\left({ }^{79}\right)$.

Moreover, ADR was found to be a nephrotoxic substance and produces chronic progressive glomerular lesions, tubular dilatation, vacuolization of renal glomeruli, protein deposits in tubular lumen and stromal fibrosis $\left.{ }^{(79}\right)$. Bertani et al. $\left.{ }^{(80}\right)$ revealed that fibrosis occurred in the interstitial zone of kidneys after administration of adriamycin and induce renal damage with glomerulosclerosis.. Rashid et al. (21) stated that rats treated with an accumulative dose of $15 \mathrm{mg} / \mathrm{kg} / \mathrm{day}$ of ADR in 6 equal intra-peritoneal injections $(2.5 \mathrm{mg} / \mathrm{kg})$ every 3 days showed dilated capillaries and urinary spaces, degenerated proximal and distal tubular epithelial cells with interrupted tubular contour, tubular congestion, presence of tubular cast and

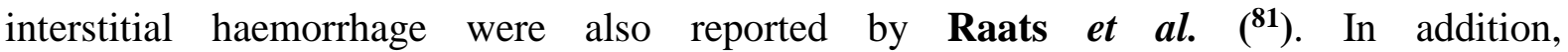
haemolysis of interstitial haemorrhage releases haemoglobin and leads to tissue accumulation of ferric ions. Free haemoglobin promotes the production of inflammation and tissue injury $\left(^{\mathbf{8 2}}\right)$. On the other hand, rat treated with Moringa in the present study showed marked improvement in tissue of kidney. This finding was in agreement with Adeyemi et al. ${ }^{\mathbf{8 3}}$ ) who showed that addition of M. oleifera to diet has a protective effect against nickel-induced nephrotoxicity in rats, the histopathology of renal tissues sections in such case revealed inimical cellular lesions caused by $\mathrm{NiSO}_{4}$ exposure. The hyaline change, thickening of glomerular wall, mild nephritis, and necrotic areas caused by $\mathrm{NiSO}_{4}$ were conspicuously absent or attenuated in the groups fed on diets containing M. oleifera. 
The histopathology presentations support the biochemical findings and confirm further the medicinal protection afforded by $M$. oleifera against drug-induced tissue damage $\left({ }^{\mathbf{8 4}}\right)$. In this respect, the nephroprotective and antioxidant effects of Moringa oleifera were investigated in paracetamol induced nephrotoxic alterations in albino rabbits $\left({ }^{\mathbf{8 4}}\right)$. In such case, moderate to severe degree of congestion was present in renal parenchyma. Also, tubular epithelial cells showed moderate degree of necrotic changes and pyknotic nuclei was observed in some tubular epithelial cells. It was reported by some author that $M$. oleifera seed powder treated animals at dose rate of $200 \mathrm{mg} / \mathrm{kg}$ body weight along with paracetamol showed pyknotic nuclei in tubular epithelial cells. Mild to moderate degree of congestion was also present. Kidney cells of $M$. oleifera seed powder treated rabbits at dose rate of $400 \mathrm{mg} / \mathrm{kg}$ body weight showed normal tubular epithelial cells with fine chromatin material. At few places mild to moderate degree of congestion was also present. While treatment with $M$. oleifera seed powder at dose rate of $600 \mathrm{mg} / \mathrm{kg}$ body weight was given orally along with paracetamol showed normal renal parenchyma and tubular epithelial cells with fine chromatin material in their nuclei. At few places within the kidney mild degree of congestion and clear urinary spaces were observed indicating complete amelioration by the plant.

Jaćević et al. $\left({ }^{68}\right)$ reported that, rats treated with DOX only, showed moderate vacuolar changes in renal tubular epithelial cells, extensive vascular changes, atrophy of some glomeruli, degeneration and reduction of tubular epithelial cells and an increase in the interstitial connective tissue. Also, the initial signs of perivascular fibrosis and marked thickening of the juxtaglomerular arteries that associated with loss of some glomeruli were also observed. Furthermore, rats treated with DOX showed dilated blood vessels, with discontinuous basal membranes surrounded by an accumulation of PMNCs. Pretreatment with amifostin (AMI) decreased the frequency and severity of described renal alterations in experimental animals both in the renal cortex and the medulla.

Although DOX toxic effects on the liver and kidney are probably mediated initially by highly reactive free radical formation, the authors hypothesized that final irreversible changes are the result of inflammatory reactions involving cells of bone marrow origin, similar to that previously demonstrated in the rat model of chronic cardiac toxicity induced by DOX ( $\left.{ }^{\mathbf{8 6}}\right)$. However Jaćević et al. $\left({ }^{\mathbf{6 8}}\right)$ showed that Amifostine (AMI), administered in rats in a dose of 75 $\mathrm{mg} / \mathrm{kg}$, before each dose of DOX, significantly attenuated the effects of this antineoplastic agent $(1.25 \mathrm{mg} / \mathrm{kg}$ ip, four consecutive days during the week. 


\section{CONCLUSION}

Hence it is recommended that the hepatoand nephrotoxicity in male albino rat could be ameliorated by moringa pre supplementation. Furthermore, carry out other investigations using different parameters as antioxidants measurements and other immunohistochemical markers to evaluate the protective effects of different antioxidants against the ADR toxicity.

\section{REFERENCES}

1. Ozaslan M, Karagoz ID, Kilic IH, Guldur ME. Ehrlich ascites carcinoma. African Journal of Biotechnology, 2013, 10(13), 2375-2378

2. Singal PK, Iliskovic N. Doxorubicin-induced cardiomyopathy. New England Journal of Medicine. 1998 Sep 24;339(13):900-5.

3. Gewirtz D. A critical evaluation of the mechanisms of action proposed for the antitumor effects of the anthracycline antibiotics adriamycin and daunorubicin. Biochemical pharmacology. 1999 Apr 1;57(7):727-41.

4. Singal P, Li T, Kumar D, Danelisen I, Iliskovic N. Adriamycin-induced heart failure: mechanisms and modulation. Molecular and cellular biochemistry. 2000 Apr 1;207(12):77-86.

5. Singal PK, Deally CM, Weinberg LE. Subcellular effects of adriamycin in the heart: a concise review. Journal of molecular and cellular cardiology. 1987 Aug 1;19(8):81728.

6. Wang Y, Wang YP, Tay YC, Harris DC. Progressive adriamycin nephropathy in mice: sequence of histologic and immunohistochemical events. Kidney international. 2000 Oct 1;58(4):1797-804.

7. Javaid B, Olson JL, Meyer TW): Glomerular injury and tubular loss in adriamycin nephrosis. J Am Soc Nephrol (2001) 12: 1391-1400.

8. Percival M. Antioxidants-A review. Clinical Nutrition Insights., Advance Nutrition Publications, (1998). 31, 201-205.

9. Dubey DK, Dora J, Kumar A, Gulsan RK. A multipurpose tree Moringa oleifera. International Journal of Pharmaceutical and Chemical Sciences. 2013 Jan;2(1):415-23.

10. Priyadarshani N, Varma MC. Effect of Moringa oleifera leaf powder on sperm count, histology of testis and epididymis of hyperglycaemic mice Mus musculus. Am. Int. J. Res. Form. Appl. Nat. Sci. 2014;7:07-13.

11. Siddiq A, Anwar F, Manzoor M, Fatima A. Antioxidant activity of different solvent extracts of Moringa oleifera leaves under accelerated storage of sunflower oil. Asian Journal of Plant Sciences. 2005;4(6):630-5. 
12. Charoensin S. Antioxidant and anticancer activities of Moringa oleifera leaves. Journal of Medicinal Plants Research. 2014 Feb 17;8(7):318-25.

13. Jahnukainen K, Jahnukainen T, Salmi TT, Svechnikov K, Eksborg S, Söder O. Amifostine protects against early but not late toxic effects of doxorubicin in infant rats. Cancer research. 2001 Sep 1;61(17):6423-7.

14. Rizk SM, Zaki HF, Mina MA. Propolis attenuates doxorubicin-induced testicular toxicity in rats. Food and chemical toxicology. 2014 May 1;67:176-86.

15. Badkoobeh P, Parivar K, Kalantar SM, Hosseini SD, Salabat A. Effect of nano-zinc oxide on doxorubicin-induced oxidative stress and sperm disorders in adult male Wistar rats. Iranian journal of reproductive medicine. 2013 May;11(5):355.

16. Bancroft JD, Gamble M. Theory and practice of histological techniques. 5th London Edinburgh New York Philadelphia St. Louis Sydney Toronto.2002; 53: 5143-5147.

17. SAS Institute. JMP: Statistics and Graphics Guide. Sas Inst; 2000.

18. Minami M, Matsumoto S, Horiuchi H. Cardiovascular side-effects of modern cancer therapy. Circulation Journal. 2010:1008100855-.

19. Minotti G, Menna P, Salvatorelli E, Cairo G, Gianni L. Anthracyclines: molecular advances and pharmacologic developments in antitumor activity and cardiotoxicity. Pharmacological reviews. 2004 Jun 1;56(2):185-229.

20. Quiles JL, Ochoa JJ, Huertas JR, LópEZ-FRíAs MA, Mataix JO. Olive oil and mitochondrial oxidative stress: studies on adriamycin toxicity, physical exercise and ageing. Olive oil and health. Oxford: CABI publishing. 2006:119-51.

21. Rashid S, Ali N, Nafees S, Ahmad ST, Arjumand W, Hasan SK, Sultana S. Alleviation of doxorubicin-induced nephrotoxicity and hepatotoxicity by chrysin in Wistar rats. Toxicology mechanisms and methods. 2013 Jun 1;23(5):337-45.

22. Ibrahim HG, Attia N, Fatma El Zahraa AH, El Heneidy MA. Cerium oxide nanoparticles: In pursuit of liver protection against doxorubicin-induced injury in rats. Biomedicine \& Pharmacotherapy. 2018 Jul 1; 103:773-81.

23. Chen S, Flower A, Ritchie A, Liu J, Molassiotis A, Yu H, Lewith G. Oral Chinese herbal medicine (CHM) as an adjuvant treatment during chemotherapy for non-small cell lung cancer: a systematic review. Lung cancer. 2010 May 1;68(2):137-45.

24. Quiles JL, Huertas JR, Battino M, Mataix J, Ramírez-Tortosa MC. Antioxidant nutrients and adriamycin toxicity. Toxicology. 2002 Oct 30;180(1):79-95.

25. Dattner AM. From medical herbalism to phytotherapy in dermatology: back to the future. Dermatologic therapy. 2003 Jun;16(2):106-13. 
26. Abdel-Aziz A M, El-Kott AF, Rabea HM. Ameliorative Effects of Garlic Extract Against Adriamycin Induced Nephrotoxicity in Ehrlich Ascites Carcinoma Bearing Male Mice. Egyptian Journal of Zoology, 2015; 174(2637), 1-26.

27. Petit T. Anthracycline- induced cardiotoxicity. Bull Cancer; (2004). 91: $195-65$.

28. Ramadan W. The protective effect of $\alpha$-lipoic acid in doxorubicin induced cardiotoxicity in rats (Doctoral dissertation).

29. Bais S, Singh GS, Sharma R. Antiobesity and hypolipidemic activity of Moringa oleifera leaves against high fat diet-induced obesity in rats. Advances in Biology. $2014 ; 2014$.

30. Hassan DI, Aya VE. Effects of Moringa oleifera leaves on Body weight and Haematological parameters of Rabbits infected with Trypanasoma congolence. Hassan, DI*, VE Aya, AI Alaku 3, Musa, SI 2, RE Barde, MM Adua 2 and ND Yusuf. PAT. 2015 Dec;11(2):253-9.

31. Zombeck JA, Fey EG, Lyng GD, Sonis ST. A clinically translatable mouse model for chemotherapy-related fatigue. Comparative medicine. 2013 Dec 1;63(6):491-7.

32. O'Keefe DA, Sisson DD, Gelberg HB, Schaeffer DJ, Krawiec DR. Systemic toxicity associated with doxorubicin administration in cats. Journal of veterinary internal medicine. 1993 Sep;7(5):309-17.

33. Saber TM, Abd El-Aziz RM, Ali HA. Quercetin mitigates fenitrothion-induced testicular toxicity in rats. Andrologia. 2016 Jun;48(5):491-500.

34. Kalender S, Kalender Y, Ates A, Yel M, Olcay E, Candan S. Protective role of antioxidant vitamin $\mathrm{E}$ and catechin on idarubicin-induced cardiotoxicity in rats. Brazilian journal of medical and biological research. 2002 Nov;35(11):1379-87.

35. Yusuf S, Hawken S, Ounpuu S, Bautista L, Franzosi MG, Commerford P, Lang CC, Rumboldt Z, Onen CL, Lisheng L, Tanomsup S. Obesity and the risk of myocardial infarction in 27000 participants from 52 countries: a case-control study. The Lancet. 2005 Nov 5;366(9497):1640-9.

36. El-Sayyad HI, Ismail MF, Shalaby FM, Abou-El-Magd RF, Gaur RL, Fernando A, Raj MH, Ouhtit A. Histopathological effects of cisplatin, doxorubicin and 5-flurouracil (5$\mathrm{FU})$ on the liver of male albino rats. International journal of biological sciences. 2009;5(5):466.

37. Ekor M, Akinrinde AO, Ogunyinka TO, Durugbo E, Odewabi AO, Kale OE, ... \& Emerole G. Moringa oleifera Leaf Extracts Modulate Biochemical Alteration Associated with Cisplatin-induced Acute Hepatic Injury in Wistar Rats. Pharmacologia, (2017) 8: 41, 51. 
38. Saluja MS, Sangameswaran B, Sharma A. Cytotoxic activity of Vitex negundo against Ehrlich Ascites Carcinoma (EAC) in mice. International Journal of PharmTech Research. 2010;2(2):1369-75.

39. Gupta A, Gautam MK, Singh RK, Kumar MV, Rao CV, Goel RK, Anupurba S. Immunomodulatory effect of Moringa oleifera Lam. extract on cyclophosphamide induced toxicity in mice. November 2010 Indian Journal of Experimental Biology (IJEB) Vol.48 (11).

40. Mahdy T, Giorgi M, Adewole T, Ernest I, Idoko M, Matey N, Ozele N, Oladipo S, Sunday M. Effect of Moringa oleifera, activated carbon and wood charcoal on biochemical and hematological parameters of Wistar rats exposed to lead acetate. Med Weter. 2012 Feb 1;68:101-6.

41. Weiss RB. The anthracyclines: will we ever find a better doxorubicin?. In Seminars in oncology 1992 Dec (Vol. 19, No. 6, pp. 670-686).

42. Al-Shabanah O, Mansour M, El-Kashef H, Al-Bekairi A. Captopril ameliorates myocardial and hematological toxicities induced by adriamycin. IUBMB Life. 1998 Jun;45(2):419-27.

43. Adedapo AA, Mogbojuri OM, Emikpe BO. Safety evaluations of the aqueous extract of the leaves of Moringa oleifera in rats. Journal of Medicinal Plants Research. 2009 Aug 31;3(8):586-91.

44. Damodar G, Smitha T, Gopinath S, Vijayakumar S, Rao YA. An evaluation of hepatotoxicity in breast cancer patients receiving injection Doxorubicin. Annals of medical and health sciences research. 2014;4(1):74-9.

45. Jung IL. Soluble extract from Moringa oleifera leaves with a new anticancer activity. PloS one. 2014 Apr 18;9(4):e95492.

46. Ichikawa Y, Ghanefar M, Bayeva M, Wu R, Khechaduri A, Prasad SV, Mutharasan RK, Naik TJ, Ardehali H. Cardiotoxicity of doxorubicin is mediated through mitochondrial iron accumulation. The Journal of clinical investigation. 2014 Feb 3;124(2):617-30.

47. Shaikh F, Dupuis LL, Alexander S, Gupta A, Mertens L, Nathan PC. Cardioprotection and second malignant neoplasms associated with dexrazoxane in children receiving anthracycline chemotherapy: a systematic review and meta-analysis. JNCI: Journal of the National Cancer Institute. 2016 Apr 1;108(4).

48. Coles EH. Veterinary clinical pathology. ed. 4th Ed W. B. Saunders Company, Philadelphia, U.S.A., 1986. 161-165.

49. Simmons JE, DeMarini DM, Berman E. Lethality and hepatotoxicity of complex waste mixtures. Environmental research. 1988 Jun 1;46(1):74-85. 
50. Berman E, House DE, Allis JW, Simmons JE. Hepatotoxic interactions of ethanol with allyl alcohol or carbon tetrachloride in rats. Journal of Toxicology and Environmental Health, Part A Current Issues. 1992 Sep 1;37(1):161-76.

51. Michael L. Bishop; Clinical chemistry, sixth edition, 2010, chapter 13:309-314

52. Anandakumar PP, Malarkodi SP, Sivaprasad TR, Saravanan GD. Antioxidant DLalpha lipoic acid as an attenuator of adriamycin induced hepatotoxicity in rat model. Indian J Exp Biol.,2007, 45:1045-1049.

53. Othman AI, El-Missiry MA, Amer MA, Arafa M. Melatonin controls oxidative stress and modulates iron, ferritin, and transferrin levels in adriamycin treated rats. Life sciences. 2008 Oct 10;83(15-16):563-8.

54. Zhao X, Zhang J, Tong N, Chen Y, Luo Y. Protective effects of berberine on doxorubicin-induced hepatotoxicity in mice. Biological and Pharmaceutical Bulletin. 2012 May 1;35(5):796-800.

55. Injac R, Boskovic M, Perse M, Koprivec-Furlan E, Cerar A, Djordjevic A, Strukelj B. Acute doxorubicin nephrotoxicity in rats with malignant neoplasm can be successfully treated with fullerenol $\mathrm{C} 60(\mathrm{OH}) 24$ via suppression of oxidative stress. Pharmacological Reports. 2008 Sep 1;60(5):742.

56. Miranda CJ, Makui H, Soares RJ, Bilodeau M, Mui J, Vali H, Bertrand R, Andrews NC, Santos MM. Hfe deficiency increases susceptibility to cardiotoxicity and exacerbates changes in iron metabolism induced by doxorubicin. Blood. 2003 Oct $1 ; 102(7): 2574-80$.

57. Mete R, Oran M, Topcu B, Oznur M, Seber ES, Gedikbasi A, Yetisyigit T. Protective effects of onion (Allium cepa) extract against doxorubicin-induced hepatotoxicity in rats. Toxicology and industrial health. 2016 Mar;32(3):551-7.

58. Burton GW. Antioxidant action of carotenoids. The Journal of Nutrition. 1989 Jan 1;119(1):109-11.

59. Lee IC, Kim SH, Baek HS, Moon C, Bae CS, Kim SH, Yun WK, Nam KH, Kim HC, Kim JC. Melatonin improves adriamycin-induced hepatic oxidative damage in rats. Molecular \& Cellular Toxicology. 2013 Sep 1;9(3):257-65.

60. Kumar E, Harsha KN, Shaik S, Rao NN, Babu NG. Evaluation of in vitro antioxidant activity and in vivo hepatoprotective activity of Moringa oleifera seeds extract against ethanol induced liver damage in Wistar rats. Evaluation. 2013 Feb;3(1):10-5.

61. Singh D, Arya P, Aggarwal V, Gupta R. Evaluation of antioxidant and hepatoprotective activities of Moringa oleifera Lam. leaves in carbon tetrachloride-intoxicated rats. Antioxidants. 2014 Sep 2;3(3):569-91. 
62. Stohs SJ, Hartman MJ. Review of the safety and efficacy of Moringa oleifera. Phytotherapy Research. 2015 Jun;29(6):796-804.

63. Sheikh A, Yeasmin F, Agarwal S, Rahman M, Islam K, Hossain E, Hossain S, Karim MR, Nikkon F, Saud ZA, Hossain K. Protective effects of Moringa oleifera Lam. leaves against arsenic-induced toxicity in mice. Asian Pacific journal of tropical biomedicine. 2014 May 1;4:S353-8.

64. Kalender Y, Yel M, Kalender S. Doxorubicin hepatotoxicity and hepatic free radical metabolism in rats: the effects of vitamin E and catechin. Toxicology. 2005 Apr 1;209(1):39-45.

65. Gokcimen A, Cim A, Tola HT, Bayram D, Kocak A, Özgüner F, Ayata A. Protective effect of $\mathrm{N}$-acetylcysteine, caffeic acid and vitamin $\mathrm{E}$ on doxorubicin hepatotoxicity. Human \& experimental toxicology. 2007 Jun;26(6):519-25.

66. Ghazal OK, Owolabi JO, William FE, Lambe E. Effects of Ethanolic Extract of Moringa Oleifera Leaves On Lead Acetate Induced Liver Damage In Adult Wistar Rats. International Journal of Biotechnology and Biomedical Research. 2012;2(1).

67. Pedrycz A, Wieczorski M, Czerny K. The influence of a single dose of adriamycin on the pregnant rat female liver-histological and histochemical evaluation. InAnnales Universitatis Mariae Curie-Sklodowska. Sectio D: Medicina 2004 (Vol. 59, No. 2, pp. 319-323).

68. Jaćević V, Dragojević-Simić V, Tatomirović Ž, Dobrić S, Bokonjić D, Kovačević A, Nepovimova E, Vališ M, Kuča K. The efficacy of amifostine against multiple-dose doxorubicin-induced toxicity in rats. International journal of molecular sciences. 2018 Aug;19(8):2370.

69. Octavia Y, Tocchetti CG, Gabrielson KL, Janssens S, Crijns HJ, Moens AL. Doxorubicin-induced cardiomyopathy: from molecular mechanisms to therapeutic strategies. Journal of molecular and cellular cardiology. 2012 Jun 1;52(6):1213-25.

70. Sakumura M, Tajiri K, Miwa S, Nagata K, Kawai K, Miyazono T, Arita K, Wada A, Murakami J, Sugiyama T. Hepatic sinusoidal obstruction syndrome induced by nontransplant chemotherapy for non-Hodgkin lymphoma. Internal Medicine. $2017 \mathrm{Feb}$ 15;56(4):395-400.

71. Hammad A, Friebel B, Begher-Tibbe A, Othman A, Vartak S, Hoehme K, Edlund I, Vonrecklinghausen D, Drasdo JG, Hengstler. Role of Binucleated Hepatocytes in Hepatotoxicity and Liver Regeneration, Naunyn-schmiedebergs Archives of Pharmacology, Springer, 233 Spring St, New York, NY 10013 USA, 2014 pp. S46S47 
72. Rašković A, Stilinović N, Kolarović J, Vasović V, Vukmirović S, Mikov M. The protective effects of silymarin against doxorubicin-induced cardiotoxicity and hepatotoxicity in rats. Molecules. 2011;16(10):8601-13.

73. Elesh HMR. Effects of Aqueous Extract of Allium sativum on Adriamycin-induced Hepatotoxicity and Nephrotoxicity in Ehrlich Ascites Carcinoma-Bearing Mice (Doctoral dissertation, FAYOUM UNIVERSITY) 2015.

74. Buraimoh AA, Bako IG, Ibrahim FB. Hepatoprotective effect of ethanolic leave extract of Moringa oleifera on the histology of paracetamol induced liver damage in Wistar rats. International Journal of Animal and Veterinary Advances. 2011 Feb 5;3(1):10-3.

75. Okasora T, Takikawa T, Utsunomiya Y, Senoh I, Hayashibara H, Shiraki K, Kasagi T, Shimizu F. Suppressive effect of superoxide dismutase on adriamycin nephropathy. Nephron. 1992;60(2):199-203.

76. El-Shitany NA, El-Haggar S, El-Desoky K. Silymarin prevents adriamycin-induced cardiotoxicity and nephrotoxicity in rats. Food and Chemical Toxicology. 2008 Jul $1 ; 46(7): 2422-8$.

77. Mansour MA, El-Kashef HA, AL-SHABANAH OA. Effect of captopril on doxorubicin-induced nephrotoxicity in normal rats. Pharmacological research. 1999 Mar 1;39(3):233-7.

78. Saad SY, Najjar TA, Al-Rikabi AC. The preventive role of deferoxamine against acute doxorubicin-induced cardiac, renal and hepatic toxicity in rats. Pharmacological research. 2001 Mar 1;43(3):211-8.

79. Yilmaz S, Atessahin A, Sahna E, Karahan I, Ozer S. Protective effect of lycopene on adriamycin-induced cardiotoxicity and nephrotoxicity. Toxicology. 2006 Feb 1;218(23):164-71.

80. Bertani T, Cutillo F, Zoja C, Broggini M, Remuzzi G. Tubulo-interstitial lesions mediate renal damage in adriamycin glomerulopathy. Kidney international. 1986 Oct 1;30(4):488-96.

81. Raats CI, Van Den Born J, Berden JH. Glomerular heparan sulfate alterations: mechanisms and relevance for proteinuria. Kidney international. 2000 Oct 1;57(2):385400.

82. Cleary CM, Moreno JA, Fernández B, Ortiz A, Parra EG, Gracia C, Blanco-Colio LM, Barat A, Egido J. Glomerular haematuria, renal interstitial haemorrhage and acute kidney injury. Nephrology Dialysis Transplantation. 2010 Aug 13;25(12):4103-6.

83. Adeyemi OS, Elebiyo TC. Moringa oleifera supplemented diets prevented nickelinduced nephrotoxicity in wistar rats. Journal of nutrition and metabolism. 2014;2014. 
84. Hannan MA, Kang JY, Mohibbullah M, Hong YK, Lee H, Choi JS, Choi IS, Moon IS. Moringa oleifera with promising neuronal survival and neurite outgrowth promoting potentials. Journal of ethnopharmacology. 2014 Feb 27;152(1):142-50.

85. Ijaz A, Javed I, Aslam B, Khan JA, Khaliq T, Khan MZ, Iqbal Z, Naeem MA, Ashraf MM. Nephroprotective and Antioxidant Effects of Moringa Oleifera (Sohanjna) in Paracetamol Induced Nephrotoxic Albino Rabbits. Pakistan Veterinary Journal. 2016 Jul 1;36(3).

86. Dragojevic-Simic VM, Dobric SL, Bokonjic DR, Vucinic ZM, Sinovec SM, Jacevic VM, \& Dogovic NP. Amifostine protection against doxorubicin cardiotoxicity in rats. Anti-cancer drugs, (2004)15(2), 169-178.

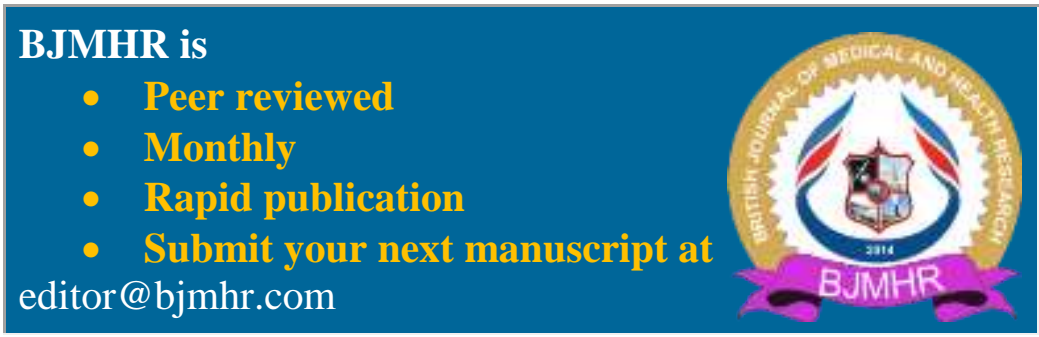

